\title{
Relationship between horizontal hydroacoustic stock estimates and gillnet catches of surface-oriented fish in shallow Lake Balaton (Hungary)
}

\author{
Á.I. György ${ }^{(1), \star}$, I. Tátrai ${ }^{(2)}$, A. Specziár ${ }^{(2)}$ \\ Received February 24, 2012 \\ Revised April 10, 2012 \\ Accepted April 25, 2012
}

\section{ABSTRACT}

Key-words: We examined whether gillnetting and hydroacoustics provide comparagillnet, side-looking hydroacoustics, comparability of data, ble relative fish density and fish size distribution estimates in the uppermost water layer of a shallow turbid lake and whether the inclusion of environmental and stock parameters could improve comparability of data between different gears. According to gillnetting, most fish shorter than $14 \mathrm{~cm}$ in total length were Alburnus alburnus, and most fish longer Alburnus alburnus, than $14 \mathrm{~cm}$ were Pelecus cultratus. Size distributions and median sizes shallow lake obtained from gillnetting and acoustics differed. Pure acoustics-derived density estimates accounted for only $<8.8 \%$ of the variation in the gillnet catch by number and no correlation was found in biomass indices. Most variances observed in the gillnet catch-per-unit-effort data were associated with water transparency, none of the other investigated variables had significant explanatory power. We conclude that the feasibility of establishing a powerful model describing the relationship between fish density estimates of gillnetting and acoustics is low in shallow and turbid habitats, and it might be successful only if the crucial sampling and environmental parameters affecting catch efficiency of gillnets and post-processing of acoustic data are considered. This study cautions again that gillnetting should be used carefully to analyse trends of fish abundance.

\section{RÉSUMÉ}

Relation entre les estimations horizontales hydroacoustiques du stock et les captures au filet maillant de poissons de surface en eaux peu profondes du lac Balaton (Hongrie)

\begin{abstract}
Mots-clés : filet maillant, hydroacoustique latérale, comparabilité des données, Alburnus alburnus, lac peu profond

Nous avons examiné si les filets maillants et l'hydroacoustique fournissent des données comparables de la densité des poissons et des estimations de distribution en taille des poissons dans la couche d'eau supérieure d'un lac peu profond trouble et si l'inclusion de paramètres environnementaux et du stock de poissons pourrait améliorer la comparabilité des données entre les différents engins. Selon la pêche au filet maillant, la plupart des poissons de longueur totale inférieure à $14 \mathrm{~cm}$ étaient Alburnus alburnus, et la plupart des poissons de plus de $14 \mathrm{~cm}$ étaient Pelecus cultratus. Les distributions de taille et les tailles médianes obtenues à partir des filets maillants et de l'acoustique sont différentes. Les estimations dérivées de la seule densité acoustique ne représentaient que moins de $8,8 \%$ de la variation des captures au filet maillant en nombre et aucune corrélation
\end{abstract}

(1) VITUKI Environmental Protection and Water Management Research Institute, Kvassay J. út 1., 1095 Budapest, Hungary

(2) Balaton Limnological Institute, Centre for Ecological Research, Hungarian Academy of Sciences, Klebelsberg K. út 3., 8237 Tihany, Hungary

* Corresponding author: gyorgyagi@gmail.com 
n'a été trouvée dans les indices de biomasse. La plupart des variations observées dans les captures par unité d'effort des filets maillants ont été associées à la transparence de l'eau, aucune des autres variables étudiées n'ont un important pouvoir explicatif. Nous concluons que la possibilité d'établir un modèle puissant décrivant la relation entre les estimations de la densité des poissons par pêche au filet maillant et de l'acoustique est faible dans les habitats peu profonds et troubles, et il ne pourrait être valable que si l'échantillonnage et les paramètres environnementaux affectant l'efficacité de capture des filets maillants et le posttraitement des données acoustiques sont considérés. Cette étude rappelle encore une fois que les filets maillants doivent être utilisés avec précaution pour analyser les tendances de l'abondance des poissons.

\section{INTRODUCTION}

The reliable estimation of biotic stock attributes is a fundamental requirement in both basic and applied research. A variety of fish sampling methods are available, which however differ in their applicability and selectivity (e.g. Murphy and Willis, 1996). With the globalization of research programs (e.g. the formation of the European Union Water Framework Directive), increasing attention has been turned to issues like the comparability of fish stock estimates over a wide range of habitats, and extended spatial and temporal scales (Holmgren and Appelberg, 2000; Mehner et al., 2005; Lauridsen et al., 2008; Deceliere-Vergés et al., 2009; Erős et al., 2009a), and the comparability of results among sampling gears (Jackson and Harvey, 1997; Olin and Malinen, 2003; Erős et al., 2009b; Winfield et al., 2009; Emmrich et al., 2010).

In standing freshwaters, sampling by gillnetting is the most widely used technique to collect fish assemblage data. The most crucial proposition of gillnet sampling is to assess how catches relate to fish abundance and size distribution. In general, it is assumed that if they are taken in a standardized manner, gillnet catches (i.e. catch per unit effort; hereafter CPUE) appropriately monitor trends of fish assemblages both in time and space (e.g. Appelberg et al., 1995; CEN, 2005). However since gillnetting is a highly selective passive fishing gear, which efficiency varies with sampling circumstances and by fish species, the relationship between the CPUE data and the fish abundance is not universal, and typically, gillnet catches cannot directly be used as an accurate estimate of relative stock density (review: Hamley, 1975; and more recently Olin et al., 2004; Linløkken and Haugen, 2006; Pierce et al., 2010; Prchalová et al., 2011). Moreover, gillnetting is a highly destructive tool, causing high mortality in captured fish, and therefore, any methodological development encouraging reduced gillnet use would be favourable (see also Winfield et al., 2009).

Because of the problems associated with gillnet sampling, the complementary use of hydroacoustics has widely been suggested (Hansson and Rudstam, 1995; Mehner and Schulz, 2002; Mous et al., 2004; Guillard and Vergès, 2007; Winfield et al., 2009; Boswell et al., 2010). Hydroacoustics is an effective tool for assessing total abundance, size distribution and habitat usage of fish, but with the exception of special situations, it does not provide species-specific information (but see Elliott and Fletcher, 2001; Winfield et al., 2009).

The existence of a positive correlation between acoustics-derived abundance estimates and gillnet CPUE values seems to be ordinary, however its strength varies strongly, and often, it is weak (Hansson and Rudstam, 1995; Mehner and Schulz, 2002; Tátrai et al., 2008; Boswell et al., 2010; Dennerline et al., 2012). Since the catching efficiency of gillnetting varies due to environmental and technical factors, a comparison of data between different gears should consider these variables. For example, Hansson and Rudstam (1995) suggested that water transparency and temperature should be taken into account when comparing gillnet catches with results from other gears (e.g. acoustics), and recently Prchalová et al. (2011) proposed the "catchable biomass" model as a potential tool for improving gillnet data comparability by adjusting soak time related biases. Though only few attempts have been made so far to 
incorporate such components into the models assessing the relationship between the data of different sampling protocols (see e.g. Hansson and Rudstam, 1995).

In this study, we tested whether gillnetting and acoustics provide comparable results on relative fish density and fish size distribution for the bleak Alburnus alburnus (L.) dominated surface water layer of shallow Lake Balaton. Sampling effort is usually not proportionally distributed across the characteristic habitats. In lakes, especially in shallow ones (i.e. water depth $<10 \mathrm{~m}$ ), the majority of the gillnetting effort is concentrated to the most diverse (i.e. more species rich) benthic fish assemblages, and surface-oriented fish are under-investigated (see e.g. CEN, 2005). Similarly, most acoustic surveys have concentrated on benthic and pelagic fish assemblages, but paid relatively little attention to surface-oriented fish mainly because of the technical limitations (i.e. near field zone, waves). However, recent studies have emphasised the importance of non-benthic fish in assessment of freshwater ecosystem processes in both deep (Kubečka and Wittingerova, 1998; Knudsen and Sægrov, 2002; Lauridsen et al., 2008; Emmrich et al., 2010) and shallow water monitoring (Olin and Malinen, 2003; Mous et al., 2004; Specziár et al., 2009). Although Lake Balaton is very shallow (mean depth is $3.2 \mathrm{~m}$ ), its fish community presents a characteristic vertical gradient regarding the species occurrence, but inevitably not the fish biomass. Recent investigations showed that about one third of the fish biomass in the open water region of the lake is represented by the surface-oriented bleak (Specziár et al., 2009).

The specific objectives of this study were to analyse how gillnet CPUE data relates to concurrent measurements from horizontal acoustic sampling in the uppermost $1.5 \mathrm{~m}$ deep water layer of Lake Balaton, and to investigate whether the inclusion of environmental parameters (i.e. water transparency, temperature and depth) and stock attributes (i.e. mean fish size and fish aggregation level) could improve comparability of data between different gears. If a strong correlation is identified, gillnet sampling could be reduced in the uppermost, species poor water layers and destructive sampling could be restricted mainly to diverse benthic and littoral fish assemblages.

\section{MATERIALS AND METHODS}

\section{> STUDY AREA}

Lake Balaton is the largest shallow lake (surface area: $593 \mathrm{~km}^{2}$; mean depth: $3.2 \mathrm{~m}$ ) in Central Europe, situated at $46^{\circ} 42^{\prime}-47^{\circ} 04^{\prime} \mathrm{N}, 17^{\circ} 15^{\prime}-18^{\circ} 10^{\prime} \mathrm{E}$ and $104.8 \mathrm{~m}$ above sea level. Its bottom is unstructured, mostly smooth, without significant fluctuation in water depth. The lake is meso-eutrophic with mean annual chlorophyll-a concentrations of $3.6-18.7 \mathrm{mg} \cdot \mathrm{m}^{-3}$ (Istvánovics et al., 2007). Forty-seven percent of the lakeshore is covered by reed grass, but submerged macrophytes occur sparsely in the littoral zone. The lake is slightly alkaline, it contains approximately $400 \mathrm{mg} \cdot \mathrm{L}^{-1}$ of $\mathrm{Ca}^{2+}$ and $\mathrm{Mg}^{2+}\left(\mathrm{HCO}_{3}^{-}\right)_{2}$, its $\mathrm{pH}$ varies between 8.2 and 9.1 , and has a conductivity of $550-671 \mu \mathrm{s} \cdot \mathrm{cm}^{-1}$. Although in exceptional cases (e.g. under ice cover) water transparency may reach $1.5-1.8 \mathrm{~m}$, in general the lake is turbid with a Secchi depth varying between $0.2 \mathrm{~m}$ and $0.8 \mathrm{~m}$. Thermal stratification do not develop in Lake Balaton, and the difference between the temperatures of the surface and the bottom water layers is always less than $2-3{ }^{\circ} \mathrm{C}$ (Herodek et al., 1988). Oxygen deficiency has never been registered in the lake, and concentrations of pollutants are low or insignificant. Common bream Abramis brama (L.), razor fish Pelecus cultratus (L.) and A. alburnus are characteristic fish species of the Lake and most abundant in biomass along with the introduced hybrid Asian carps Hypophthalmichthys. There are several reviews on the limnology (e.g. Herodek et al., 1988; Istvánovics et al., 2007) and the fish fauna (e.g. Bíró, 1997; Specziár 2010) of Lake Balaton, which can serve as a source of further information. 


\section{Table I}

Survey dates, environmental parameters and basic acoustics-derived characteristics (at target strength $\geqslant-55 \mathrm{~dB}$ ) of the fish stock in the uppermost $1.5 \mathrm{~m}$ water layer of Lake Balaton.

\begin{tabular}{|l|c|c|c|c|c|c|c|}
\hline Trial & Date & $\begin{array}{c}\text { Water } \\
\text { depth } \\
(\mathrm{cm})\end{array}$ & $\begin{array}{c}\text { Secchi } \\
\text { depth } \\
(\mathrm{cm})\end{array}$ & $\begin{array}{c}\text { Water } \\
\text { temperature } \\
\left({ }^{\circ} \mathrm{C}\right)\end{array}$ & $\begin{array}{c}\text { Single } \\
\text { echoes } \\
(\%)\end{array}$ & $\begin{array}{c}\text { Mean } \\
\text { acoustic } \\
L(\mathrm{~cm})\end{array}$ & $\begin{array}{c}\text { Mean } \\
A_{\text {Tot }} \\
\left(\text { (fish 1000 } \cdot \mathrm{m}^{-3}\right)\end{array}$ \\
\hline $\mathbf{1 .}$ & 19.04 .2007 & 450 & 47 & 14.0 & 85.8 & 15.4 & 19.1 \\
\hline $\mathbf{2 .}$ & 11.05 .2007 & 335 & 66 & 18.6 & 61.6 & 18.5 & 6.4 \\
\hline $\mathbf{3 .}$ & 31.05 .2007 & 415 & 54 & 18.6 & 52.7 & 16.4 & 32.1 \\
\hline $\mathbf{4 .}$ & 20.09 .2007 & 425 & 45 & 14.6 & 2.2 & 16.2 & 54.1 \\
\hline $\mathbf{5 .}$ & 21.09 .2007 & 390 & 44 & 15.1 & 70.2 & 12.9 & 39.9 \\
\hline $\mathbf{6 .}$ & 26.09 .2007 & 400 & 100 & 16.2 & 48.0 & 8.4 & 17.2 \\
\hline $\mathbf{7 .}$ & 15.04 .2009 & 470 & 85 & 13.0 & 35.9 & 20.9 & 0.9 \\
\hline $\mathbf{8 .}$ & 21.07 .2009 & 415 & 68 & 23.6 & 47.9 & 10.2 & 10.7 \\
\hline $\mathbf{9 .}$ & 23.07 .2009 & 460 & 77 & 24.5 & 50.5 & 10.1 & 12.1 \\
\hline $\mathbf{1 0 .}$ & 27.07 .2010 & 330 & 38 & 19.9 & 89.6 & 14.6 & 10.3 \\
\hline $\mathbf{1 1 .}$ & 28.07 .2010 & 400 & 46 & 19.9 & 62.7 & 18.7 & 18.3 \\
\hline $\mathbf{1 2 .}$ & 29.07 .2010 & 460 & 54 & 21.1 & 74.2 & 16.4 & 5.1 \\
\hline $\mathbf{1 3 .}$ & 30.07 .2010 & 410 & 48 & 21.1 & 47.6 & 19.1 & 3.8 \\
\hline & Mean \pm SD & $412 \pm 44$ & $59 \pm 19$ & $18.5 \pm 3.7$ & $60.7 \pm 15.9$ & $15.2 \pm 3.9$ & $17.7 \pm 15.6$ \\
\hline
\end{tabular}

$L$ : total length; $A_{\text {Tot }}$ : volumetric acoustic abundance based on the amplitude-echogram.

\section{> DATA SAMPLING AND PROCESSING}

Thirteen gillnetting and concurrent acoustic surveys were conducted in the uppermost $1.5 \mathrm{~m}$ water layer during the day-time in 2007, 2009 and 2010 in the open water area of Lake Balaton (Table I). Sampling trials were distributed in time and space to provide useful gradients of both fish density and environmental circumstances. In order to exclude effects of diel changes in fish behaviour (i.e. activity, diel vertical migration), all samplings were initiated at 8 a.m. conforming also to the diel activity pattern of bleak. Unlike most other temperate freshwater fish, bleak is more active at day-time than at night-time, especially in waters with low transparency (Olin and Malinen, 2003; Prchalová et al., 2010; but see Vašek et al., 2009 for a more transparent habitat). Considering the high sensitivity of horizontal acoustics to the stability of the beam orientation and the signal-to-noise ratio, all samplings were carried out on windless days.

For the experiments, surface-set multimesh gillnets (Nippon Verkko oy, Finland) were used. Gillnets were made according to the European standard EN 14757 (CEN, 2005) for benthic gillnets but with a modified buoyancy line enabling the surface setting of the net. They composed of 12 different mesh-sizes ranging from 5 to $55 \mathrm{~mm}$ (knot to knot) and were $1.5 \mathrm{~m}$ deep. The order of the panels of different mesh-sizes was fixed as $43,19.5,6.25,10,55,8$, $12.5,24,15.5,5,35$ and $29 \mathrm{~mm}$. Each mesh panel was $2.5 \mathrm{~m}$ long and mounted on a $30 \mathrm{~m}$ long buoyancy line (linear density in water $31 \mathrm{~g} \cdot \mathrm{m}^{-1}$ ) and a $33 \mathrm{~m}$ long lead line (linear density in air $22 \mathrm{~g} \cdot \mathrm{m}^{-1}$ ). The hanging ratio was 0.5 for all mesh-sizes.

In each trial, three surface-set gillnets were positioned linearly with one net length gap between them. In order to avoid the saturation of nets with fish and the related biases (Olin et al., 2004; Prchalová et al., 2011), soak time must be kept short in Lake Balaton (Erős et al., 2009b; Specziár et al., 2009). Therefore, we used sampling intervals of two hours.

Catches from each net were processed separately. Captured fish were identified, counted by species, measured to the nearest millimetre total lengths $(L)$, and weighted to the nearest gram wet mass $(M)$. Gillnet catches were expressed in both NPUE (number of fish captured per one hour per net) and BPUE (mass of fish captured per one hour per net).

Concurrent horizontal acoustic measurements were carried out by means of a SIMRAD EK60 split-beam echo sounder with $120 \mathrm{kHz}$ operating frequency and equipped with an E120-7C transducer (circular beam with a nominal beam angle of $7^{\circ} \times 7^{\circ}$ ). The transducer was mounted 
on a pole fixed to the bow of a boat, $0.4 \mathrm{~m}$ under the water surface and aimed perpendicular to the sailing route. The axis of the beam was tilted $3.5^{\circ}$ below horizontal as the upper margin of the sound beam run approximately parallel with the water surface. The system's operating power was $100 \mathrm{~W}$, the pulse duration $0.128 \mathrm{~ms}$, the ping rate $10 \mathrm{ping} \cdot \mathrm{s}^{-1}$, the bandwidth $10.92 \mathrm{kHz}$ and the recording threshold $-100 \mathrm{~dB}$. Based on the results of Godlewska et al. (2011), short pulse duration was chosen to enable target separation in the densely populated uppermost water layer of Lake Balaton. The echosounder system was calibrated before each trial with a $23 \mathrm{~mm}$ copper calibration sphere with reference target strength (TS) of $-40.4 \mathrm{~dB}$ at $120 \mathrm{kHz}$. In each trial, three consecutive acoustic measurements, each lasting for approximately $10 \mathrm{~min}$, with $15 \mathrm{~min}$ gaps between them were made along an approximately $1200 \mathrm{~m}$ long elliptical route (with a major radius being approx. $280 \mathrm{~m}$ long and coinciding with the axis of the nets; and the minor radius being approx. $50 \mathrm{~m}$ long and being perpendicular to the nets) around the gillnets, measuring outwards. First acoustic measurement started $15 \mathrm{~min}$ after the set of the nets. Second and third acoustic runs followed the same route set during the first run based on GPS navigation.

Acoustic raw data was converted and analysed using Sonar5-Pro post-processing software (Balk and Lindem, 2007). To enable a more detailed statistical analysis (i.e. the comparison of three consecutive measurements for each trial), each acoustic measurement (i.e. data of one lap along the $1200 \mathrm{~m}$ long route around the nets) was divided into five elementary distance sampling units (EDSU) of equal length (i.e. $240 \mathrm{~m}$ ). For this study, acoustic data were processed to $12 \mathrm{~m}$ distance from the transducer (excluding the near-field range of the transducer) corresponding to the uppermost $1.5 \mathrm{~m}$ water layer. Sonar-5-Pro's cross-filter detector (CFD) was used to reduce noise related bias in the single echo detection (SED) echograms and to improve the quality of the data (Balk, 2001; see also Rakowitz et al., 2009; Tušer et al., 2009). Both the height and the width of the CFD's foreground filter was set to 1 ; the background filter height was between 23-29, the width between 1-13, and the offset was $+6 \mathrm{~dB}$. Volumetric fish abundance $(A)$ and biomass $(B)$ was assessed by the $S_{v} / T S$ scaling method ( $A_{\text {Tot }}, B_{\text {Tot }}$ from the amplitude-echogram and $A_{\text {SED }}, B_{\text {SED }}$ from the SED-echogram, respectively) (Balk and Lindem, 2007). Linear volume reverberation $\left(S_{v}\right)$ and mean TS (calculated in the linear domain) were determined based on SEDs for each EDSU (15 EDSUs per trial). Since the records were relatively noisy, TS threshold was set to $-55 \mathrm{~dB}$ (equivalent to a $L=2.5 \mathrm{~cm}$ fish at side aspect; Frouzová et al., 2005). Suitability of conditions for a reliable TS estimation was checked by the Sawada index; and its value proved to be less than 0.1 in each case. Target strength values of single echoes recorded at random aspects were converted to side aspect TS values using the deconvolution method of Kubečka et al. (1994), and then to $L$ according to the lateral aspect regression for European freshwater species by Frouzová et al. (2005). For calculating $B$, mean $L(\mathrm{~cm})$ of each $1 \mathrm{~cm}$ acoustic $L$ groups were converted to $M(\mathrm{~g})$ according to the corresponding relationships for bleak $\left(M=0.00720 L^{3.102}\right)$ and razor fish $\left(M=0.00576 L^{3.041}\right)$ determined from gillnet catches, and then multiplied with the estimated $A$ of the given $L$ group. All targets with an estimated $L$ up to $14 \mathrm{~cm}$ were considered to be bleak, and all larger targets were considered to be razor fish (see results).

Water temperature $\left({ }^{\circ} \mathrm{C}\right)$ measured at $0.5 \mathrm{~m}$ under the water surface, depth $(\mathrm{cm})$ and transparency measured as Secchi depth $(\mathrm{cm})$ were recorded at each trial. It is well known that the accuracy of acoustic density estimates depends upon the detectability of individual fish as single targets, which however is a function of distance between fish in the shoal. Hence, we characterized the "aggregation level" of fish based on the ratio of $A_{\text {Tot }} A_{\mathrm{SED}}^{-1}$, which is the converse of the ratio of $S_{v}$ from single echoes and the total $S_{v}$ in the sampled volume calculated by the Sonar5-Pro post-processing software. Finally, since the efficiency of gillnets varies with fish size, we also considered mean acoustic $L$ as a potential explanatory variable for the model assessing the relationship between the density estimates of gillnetting and acoustics. 


\section{> STATISTICAL ANALYSIS}

Since fright reaction of fish can bias the results of acoustics (Draštic and Kubečka, 2005; Godlewska et al., 2009), and surface-oriented fish, like bleak, are supposed to be especially sensitive for the presence of the survey boat (Janáč and Jurajda, 2005), thus first it was examined whether avoidance of the survey boat by fish could influence results of the acoustics. It was hypothesized that if the boat frightens fish, then their density and size distribution should change in the sampling area during the continuous disturbance. Therefore, results of the three consecutive rounds (data of five EDSUs for each) of the acoustic sampling were tested for significant differences in $A_{\text {Tot }}, A_{\text {SED }}$ and mean acoustic $L$ with analysis of variance (ANOVA) performed on $\log _{10}(x+1)$ transformed data, both for each individual trial and for the whole study.

Total length distributions derived from gillnetting and acoustics were compared with nonparametric Kolmogorov-Smirnov two-sample test and Mann-Whitney U-test separately for each individual trial. Comparisons were made over both the whole fish size range represented in the gillnet catches $(L=5-35 \mathrm{~cm})$ and the size range of bleak $(L=5-14 \mathrm{~cm})$ only.

Relationship between the gillnet catches (dependent variable) and the acoustics-derived density estimates, and other explanatory variables were investigated with multiple linear regression analysis using the forward stepwise variable selection procedure (at $p<0.05$ ). Other parameters examined were the water temperature, Secchi depth, water depth and aggregation level and mean acoustic $L$ of fish. Prior to analyses gillnet CPUE data and acoustic fish density estimates $\left(A\right.$ and $B$ ) were $\log _{10}(x+1)$ transformed and other variables were $\log _{10} X$ transformed. Explanatory variables were largely independent, except the relationship between the Secchi depth and aggregation level of fish (Pearson's correlation, $r=0.730, p<0.005$ ). Latter two variables were therefore investigated separately.

A comparison between gears was attempted for both abundance (i.e. NPUE vs. $A_{\text {Tot }}$ or $A_{\text {SED }}$ ) and biomass (i.e. BPUE vs. $B_{\text {Tot }}$ or $B_{\text {SED }}$ ) related estimates using data over both the whole fish size range represented in the gillnet catches $(L=5-35 \mathrm{~cm})$ and the size range of bleak only $(L=5-14 \mathrm{~cm})$. Where it was relevant, regression analyses were completed with variation partitioning procedure to quantify the contribution of each explanatory variable to the explained variance in the gillnet CPUE data.

All statistical analyses were performed in Statistica 8.0 (StatSoft, Inc.).

\section{RESULTS}

\section{> GILLNETTING}

Altogether 4889 fish belonging to five species were captured during the 13 trials (39 gillnet sets) in the uppermost $1.5 \mathrm{~m}$ water layer of Lake Balaton at 3.3-4.7 m water depth (Table II). In gillnet catches, bleak dominated in both number (mean: 98.7\%) and biomass (mean: $83.5 \%$ ). Other fish captured were razor fish and as singletons roach Rutilus rutilus (L.), asp Aspius aspius (L.) and pikeperch Sander lucioperca (L.). Except three specimens, all $L<14 \mathrm{~cm}$ fish caught were bleak; and except two all $L>14 \mathrm{~cm}$ fish were razor fish. Catch per unit effort values varied within the ranges of 2.2-177 (62.7 \pm 55.7 ; mean $\pm \mathrm{SD})$ fish $\cdot \mathrm{h}^{-1} \cdot$ net $^{-1}$ and 11.6-1666 (588 \pm 556$) \mathrm{g} \cdot \mathrm{h}^{-1} \cdot$ net $^{-1}$ in NPUE and BPUE, respectively.

\section{> HYDROACOUSTICS}

Acoustic abundance estimates varied over the 13 trials in the range of $0.9-54.1$ (17.7 \pm 15.6) fish 1000 $\mathrm{m}^{-3}$ (ANOVA, $F_{12,180}=71.7, p<0.001$ ) and 0.3-33.7 (11.2 \pm 10.1) fish $1000 \cdot \mathrm{m}^{-3}$ (ANOVA, $F_{2,180}=83.0, p<0.001$ ) for $A_{\text {Tot }}$ and $A_{\mathrm{SED}}$, respectively. However, acoustic abundance estimates, based either on $A_{\text {Tot }}$ or $A_{\mathrm{SED}}$, did not differ among the three consecutive measurements in 11 out of the 13 trials (ANOVA, $p>0.05$; Table III), as well as for the 


\section{Table II}

Number $(N)$ and mass $(M, g)$ of fish captured, their mean total length $(L, c m)$, and mean catch per unit effort values by number (NPUE, fish $\cdot h^{-1} \cdot$ net $^{-1}$ ) and biomass (BPUE, $g \cdot h^{-1} \cdot$ net $^{-1}$ ) in gillnet samples in the uppermost $1.5 \mathrm{~m}$ water layer of Lake Balaton.

\begin{tabular}{|l|c|c|c|c|c|}
\hline \multirow{2}{*}{ Species } & \multicolumn{2}{|c|}{ Sample size } & $L$ & NPUE & BPUE \\
\cline { 2 - 6 } & $N$ & $M$ & Mean \pm SD (min.-max. $)$ & Mean \pm SD & Mean \pm SD \\
\hline Rutilus rutilus & 1 & 324 & $25.8 \pm 0(25.8-25.8)$ & $0.02 \pm 0.06$ & $5.09 \pm 18.3$ \\
\hline Aspius aspius & 1 & 242 & $29.1 \pm 0(29.1-29.1)$ & $0.01 \pm 0.04$ & $2.48 \pm 8.95$ \\
\hline Alburnus alburnus & 4823 & 38282 & $9.0 \pm 1.8(5.0-13.6)$ & $61.8 \pm 55.5$ & $491 \pm 511$ \\
\hline Pelecus cultratus & 63 & 6942 & $23.0 \pm 5.6(9.5-32.5)$ & $0.80 \pm 0.93$ & $89.0 \pm 113$ \\
\hline Sander lucioperca & 1 & 11 & $10.2 \pm 0(10.2-10.2)$ & $0.01 \pm 0.05$ & $0.15 \pm 0.53$ \\
\hline Total sample & 4889 & 45826 & & $62.7 \pm 55.7$ & $588 \pm 556$ \\
\hline
\end{tabular}

\section{Table III}

Results of the ANOVA statistics of horizontal acoustics-derived fish abundance estimates from the amplitude-echograms $\left(A_{\text {Tot }}\right)$ and single echo detection echograms ( $\left.A_{\mathrm{SED}}\right)$, and total length $(L)$ during the three consecutive acoustic measurements (each divided into five subsamples, EDSU) of 13 surveys in the uppermost $1.5 \mathrm{~m}$ water layer in Lake Balaton.

\begin{tabular}{|l|c|c|c|c|c|c|c|}
\hline \multirow{2}{*}{ Trial } & \multirow{2}{*}{ df. } & \multicolumn{2}{|c|}{$A_{\text {Tot }}$} & \multicolumn{2}{|c|}{$A_{\text {SED }}$} & \multicolumn{2}{|c|}{$L$} \\
\cline { 3 - 8 } & $F$ & $p$ & $F$ & $p$ & $F$ & $p$ \\
\hline $\mathbf{1 .}$ & 2.12 & 0.42 & 0.664 & 0.80 & 0.470 & 1.45 & 0.272 \\
\hline $\mathbf{2 .}$ & 2.12 & 3.47 & 0.064 & 1.41 & 0.281 & 3.77 & 0.054 \\
\hline $\mathbf{3 .}$ & 2.12 & 8.75 & $0.005^{*}$ & 7.53 & $0.008^{*}$ & 0.12 & 0.884 \\
\hline $\mathbf{4 .}$ & 2.12 & 0.53 & 0.599 & 0.82 & 0.463 & 0.36 & 0.703 \\
\hline $\mathbf{5 .}$ & 2.12 & 0.28 & 0.762 & 0.36 & 0.705 & 1.28 & 0.314 \\
\hline $\mathbf{6 .}$ & 2.12 & 0.21 & 0.812 & 2.15 & 0.159 & 0.10 & 0.908 \\
\hline $\mathbf{7 .}$ & 2.12 & 2.36 & 0.136 & 0.66 & 0.537 & 0.28 & 0.759 \\
\hline $\mathbf{8 .}$ & 2.12 & 0.85 & 0.451 & 0.68 & 0.525 & 0.00 & 0.996 \\
\hline $\mathbf{9 .}$ & 2.12 & 1.20 & 0.334 & 1.67 & 0.228 & 0.92 & 0.425 \\
\hline $\mathbf{1 0 .}$ & 2.12 & 5.37 & $0.022^{*}$ & 5.53 & $0.020^{*}$ & 2.45 & 0.128 \\
\hline $\mathbf{1 1 .}$ & 2.12 & 2.80 & 0.100 & 0.35 & 0.712 & 1.50 & 0.262 \\
\hline $\mathbf{1 2 .}$ & 2.12 & 1.26 & 0.319 & 2.41 & 0.132 & 0.73 & 0.504 \\
\hline $\mathbf{1 3 .}$ & 2.12 & 1.32 & 0.304 & 1.72 & 0.221 & 0.04 & 0.964 \\
\hline
\end{tabular}

* Note that the differences are not significant $(p>0.05)$ if the Bonferroni correction of significance level for multiple comparisons is considered.

whole study (Figure 1). Mean acoustic $L$ ranged from 8.4 to $20.9 \mathrm{~cm}(15.2 \pm 3.9)$ and differed significantly among (ANOVA, $F_{12,180}=27.8, p<0.001$ ) but not within trials (Table III and Figure 1). Correspondingly, it is likely that research boat induced avoidance reaction of fish was insignificant.

\section{>RELATIONSHIP BETWEEN GILLNETTING AND HYDROACOUSTICS}

For the entire fish size range $(L=5-35 \mathrm{~cm})$ investigated, gillnetting and acoustics provided different fish size distribution estimates for most of the individual trials and the global samples pooled over the 13 trials (Table IV). The most obvious difference between the two gears was that gillnetting underestimated the share of larger (i.e. $L>14 \mathrm{~cm}$ ) fish compared to acoustics. When only the $L=5-14 \mathrm{~cm}$ fish (i.e. bleak) were considered, consistency between the estimates of the two gears improved, but they still often differed significantly. Due to their low representation in the gillnet catches, size distribution of $L=14-35 \mathrm{~cm}$ fish could be compared for pooled samples only, which proved also to be different (Kolmogorov-Smirnov two-sample test, $p<0.025$; Mann-Whitney $U$-test, $Z=-2.57, p=0.010)$. In gillnet catches, this size range was represented by four separate size classes of razor fish peaking at 15,21 , 27 and $29 \mathrm{~cm} \mathrm{~L}$, which were however not identified by the acoustics (Figure 2). 


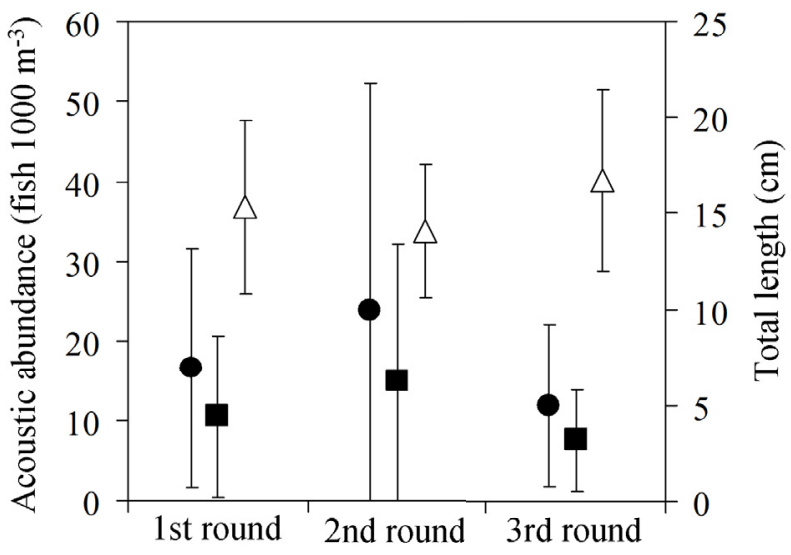

Acoustic surveys

\section{Figure 1}

Changes (mean $\pm S D$ ) of horizontal acoustics-derived fish abundance estimates from the amplitudeechograms (filled circles) and single echo detection echograms (filled squares), and total length (empty triangles) during three consecutive acoustic measurements of 13 surveys in the uppermost $1.5 \mathrm{~m}$ water layer in Lake Balaton. Neither variables differed among the three consecutive acoustic measurements (each divided into five subsamples, EDSU) at the level of the whole study (ANOVA, $F_{2,180}=1.9-2.54$, $p=0.084-0.153)$, and in general, the same result was obtained at the level of individual trials (for statistics, see Table III).

Regression analyses showed that gillnet catches were only weakly related to acousticsderived density estimates, and just for abundance data (i.e. NPUE vs. $A_{\text {Tot }}$ and $A_{\mathrm{SED}}$ ) (Figure 3 ). Moreover, of the investigated complementary variables only water transparency (measured as Secchi depth) correlated with the gillnet CPUE data. The negative correlation between the Secchi depth and the gillnet CPUE was strong $\left(R_{\text {adj. }}^{2}=0.770-0.825, p<0.001\right)$ (for $L=5-35 \mathrm{~cm}$ see also Figure 4). Established multiple linear regression models predicted gillnet NPUE and BPUE well, and explained $77 \%$ to $86 \%$ of the total variance in these variables (Table V, Figure 5). Variance partitioning showed that most of the explained variance was associated with the water transparency, and acoustics-derived fish density had only minor separate influence ( $\leqslant 8.8 \%$ of the total variance) on gillnet catches. However, the shared effect of water transparency and acoustics-derived fish density was also substantial in NPUE (Table V).

\section{DISCUSSION}

In accordance with other studies (Hansson and Rudstam, 1995; Boswell et al., 2010; Dennerline et al., 2012), we found that gillnet catches hardly correlated with fish density estimates obtained from an acoustic survey, which is the most widely suggested complementary tool to improve and calibrate gillnet data. Pure acoustics-derived density estimates accounted for $<8.8 \%$ of the variation in the gillnetting NPUE data, but they contributed insignificantly to regression models describing BPUE. Analyses showed that most of the variance in the gillnet CPUE data was associated with water transparency. Moreover, because of the absence of a meaningful relationship between the gillnet catch and acoustics-derived fish density, even the relevance of gillnet data for monitoring trends of fish abundance seems to be problematic.

Gillnet CPUE correlated negatively with water transparency, indicating a higher catchability of fish under poor visibility. Hansson and Rudstam (1995) found a similar but less strong correlation in Baltic Sea herring Clupea harengus L. and sprat Sprattus sprattus (L.). They also reported that a regression model including both acoustic abundance and water transparency explained an extra $10 \%$ (altogether $38 \%$ ) of variance in the gillnetting NPUE data compared to the model based solely on acoustic data. Water transparency can influence gillnetting 


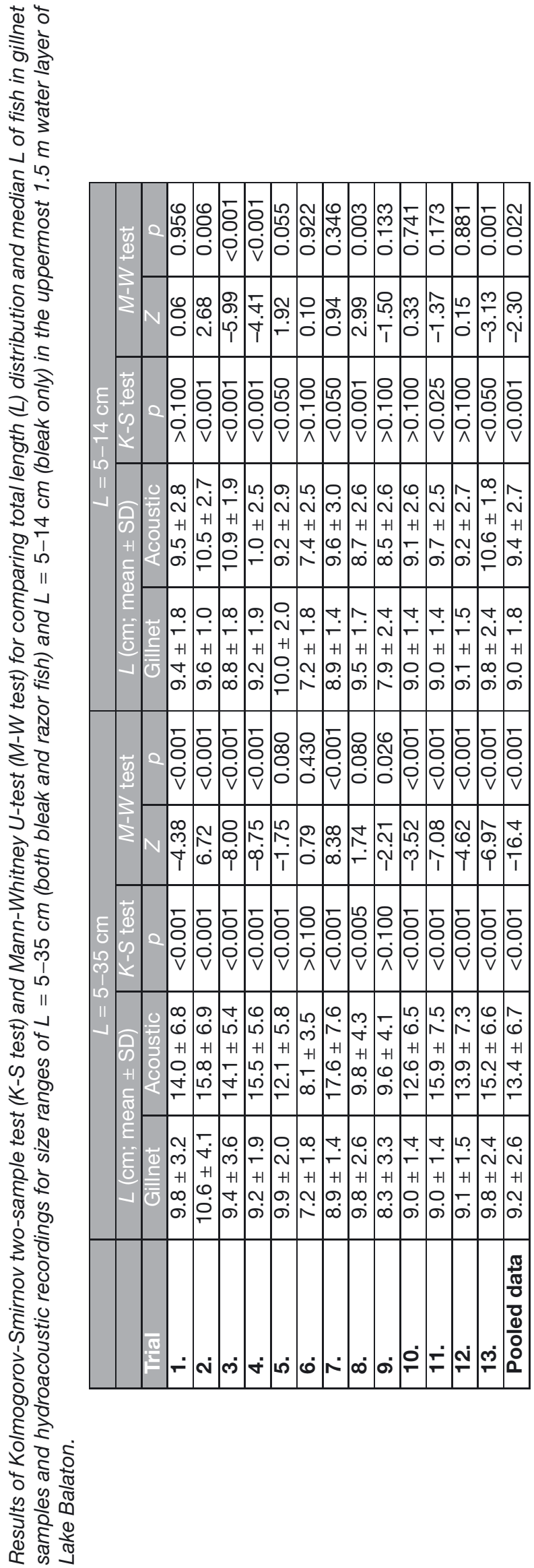




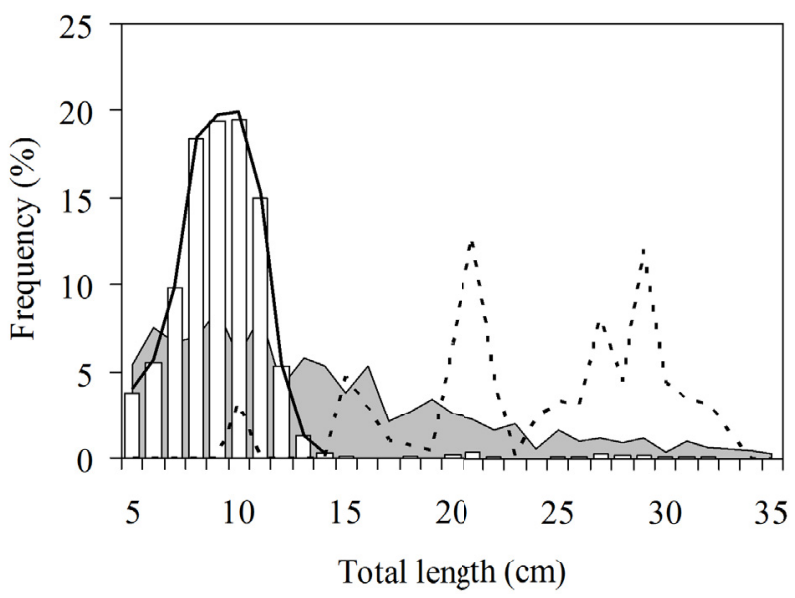

\section{Figure 2}

Average relative total length $(L)$ distribution of fish assessed by gillnetting (empty bars) and horizontal acoustics (grey shaded area) for the size range of $L=5-35 \mathrm{~cm}$ in the uppermost $1.5 \mathrm{~m}$ water layer of Lake Balaton. Size distributions of bleak (continuous line) and razor fish (broken line) in the gillnet catches are also indicated. For between gear statistics, see Table IV.

efficiency at least in two ways. Firstly, in turbid water the probability that a fish observes the net before being entangled is lower than in clear water. Secondly, activity of most fishes is influenced by light intensity, being highest at low light but not in complete darkness (Gjelland et al., 2004 and references therein). In Lake Balaton, the transparency of the water may vary between 0.2 and $1.8 \mathrm{~m}$ measured as Secchi depth, depending on the instantaneous biomass of planktonic algae and the winds. Since Lake Balaton is a large but shallow lake, a wind over 1 to $4 \mathrm{~m} \cdot \mathrm{s}^{-1}$ disturbs the loose sediment and disperses the solid particles in the whole water body (Herodek et al., 1988). Consequently, even day-to-day or site-to-site variation in the water transparency may be considerable, and thus, it can bias gillnet-based fish density indices even at these scales, at least in the uppermost water layer. Accordingly, variations in the water transparency should be considered when comparing gillnet data over sampling sites or dates, and with results of other methods.

Water temperature is undoubtedly one of the most important factors influencing the activity and behaviour of fish. Fish activity and swimming speed supposedly increase with water temperature, and accordingly the efficiency of gillnetting is expected to increase as well (Linløkken and Haugen, 2006). In contrary to the above hypothesis, but in accordance with the observations of Hansson and Rudstam (1995), we did not identify a significant temperature effect in gillnet catches.

Corresponding to other observations (Mehner and Schulz, 2002; Boswell et al., 2007, 2010), size distribution and median size estimates obtained from gillnetting and acoustics differed. It is well known that gillnetting is a highly size selective gear, and in general, it underestimates the presence of small fish (Hamley, 1975; Olin and Malinen, 2003; Prechalová et al., 2009). On the contrary, we found a higher share of small fish in gillnet catches than estimated by acoustics. Since we performed our surveys at day-time, therefore it could be a logical explanation that gillnetting overestimated the share of small-sized day-time foragers like bleak, and underestimated larger fish, which may however be active only at twilight or complete darkness. Based on gillnet catches, the sole species occurring regularly in the uppermost water layer within the $L=14-35 \mathrm{~cm}$ size range was razor fish. This species is also active during the day-time and can be captured effectively, especially in water layers somewhat deeper than investigated here (Specziár et al., 2009; Specziár, 2010). Razor fish represented in gillnet catches in discrete size classes that were however not mirrored in acoustic data. Similar phenomenon was observed by Boswell et al. (2007) in very shallow estuarine habitats in Louisiana. There are several formulas in use, which were developed on theoretical basis to adjust gillnet catches for size selectivity. However, these indirect techniques do not take into 

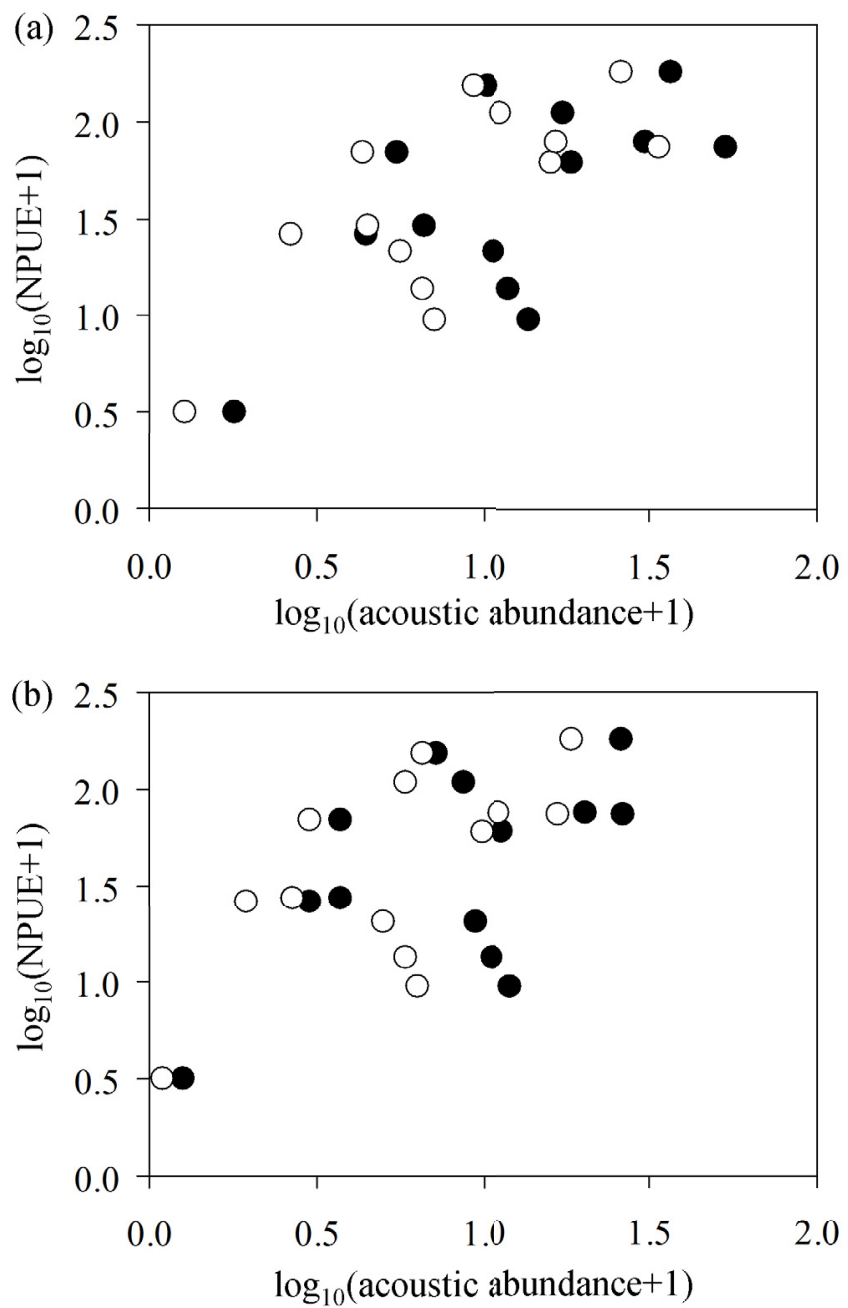

\section{Figure 3}

Relationship between hydroacoustic fish density estimates based on the amplitude-echograms $\left(A_{\text {Tot }}\right.$, fish $1000 \cdot \mathrm{m}^{-3}$; filled circles); and single echo detection echogram ( $A_{\mathrm{SED}}$, fish $1000 \cdot \mathrm{m}^{-3}$; empty circles), and gillnet catch per unit effort by abundance (NPUE, fish $\cdot h^{-1} \cdot$ net $\left.^{-1}\right)$ for fish total length $(L, c m)$ ranges of (a) $L=5-35 \mathrm{~cm}$ (both bleak and razor fish) and (b) $L=5-14 \mathrm{~cm}$ (bleak only) in the uppermost $1.5 \mathrm{~m}$ water layer of Lake Balaton. Note that data are $\log _{10}(x+1)$ transformed; and all relationships were insignificant for biomass data. Linear regression statistics: (a) $\log _{10}(N P U E+1)=0.82 \log _{10}\left(A_{\text {Tot }}+1\right)+0.70, R_{\text {adj. }}^{2}=0.361$, $p=0.018 ; \log _{10}(N P U E+1)=0.95 \log _{10}\left(A_{\mathrm{SED}}+1\right)+0.74, R_{\mathrm{adj}}^{2}=0.500, p=0.004 ;(b) \log _{10}(N P U E+1)=$ $0.74 \log _{10}\left(A_{\text {Tot }}+1\right)+0.91, R_{\text {adj. }}^{2}=0.253, p=0.046 ; \log _{10}(N P U E+1)=0.95 \log _{10}\left(A_{\mathrm{SED}}+1\right)+0.88, R_{\mathrm{adj} .}^{2}=$ $0.387, p=0.014$.

account species-specific behavioural and activity patterns, and therefore provide ambiguous results (Millar, 2000; Prechalová et al., 2009). Since size-specific processes were assumed to occur, we tested whether the inclusion of the mean acoustics-derived fish size would gain more explained variance in gillnet catches, but it did not.

Most of the discrepancies between the estimates of the two gears studied could undoubtedly be explained by the highly selective nature of gillnetting, but not necessarily only by that. The accuracy of acoustics in estimating fish density and size distribution is theoretically high, and for the assessment of pelagic fish stocks, the acoustic technique is at least as good as, and probably better than any other (Simmonds and MacLennan, 2005). Yet, there are some sources of potential biases that may influence acoustic estimates, too. Mobile acoustic equipments are operated from vessels, which may induce a fright reaction in fish, and thereby affect fish density and size distribution estimates (Draštic and Kubečka, 2005; Godlewska 


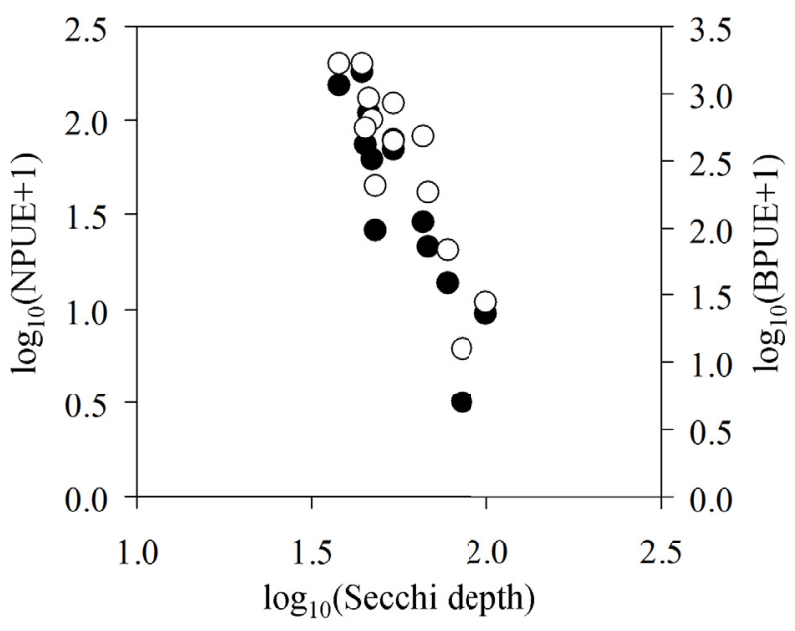

\section{Figure 4}

Correlation between Secchi depth (cm), gillnet catch per unit effort data by number (NPUE, fish $\cdot h^{-1} \cdot$ net $^{-1}$; filled circles) and biomass (BPUE, $g \cdot h^{-1} \cdot$ net $^{-1}$; empty circles) for fish total length (L) range of $L=5-35 \mathrm{~cm}$ (both bleak and razor fish) in the uppermost $1.5 \mathrm{~m}$ water layer of Lake Balaton. Note that data are logarithmic transformed. Linear regression statistics: $\log _{10}(\mathrm{NPUE}+1)=-3.59 \log _{10}($ Secchi depth)+7.90, $R_{\mathrm{adj} .}^{2}=0.770, p<0.001 ; \log _{10}(\mathrm{BPUE}+1)=-4.61 \log _{10}($ Secchi depth $)+10.57, R_{\mathrm{adj} .}^{2}=0.771, p<0.001$.

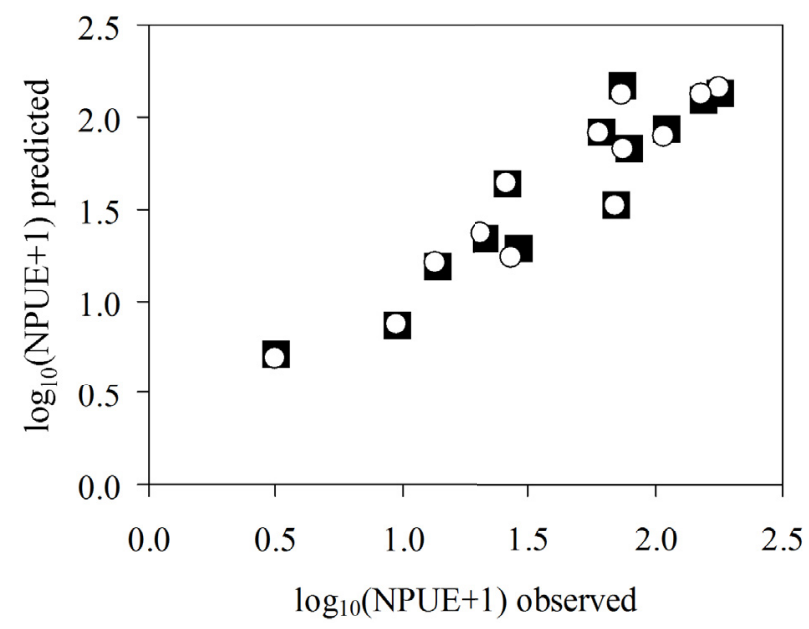

\section{Figure 5}

Correlation between observed and predicted gillnet catch per unit effort data by number (NPUE, fish $\cdot h^{1} \cdot$ net $^{-1}$ ) for fish total length ( $L$ ) ranges of $L=5-35 \mathrm{~cm}$ (both bleak and razor fish) (filled squares) and $L=5-14 \mathrm{~cm}$ (bleak only) (empty circles) in the uppermost $1.5 \mathrm{~m}$ water layer of Lake Balaton. Multiple linear regression models are based on Secchi depth $(\mathrm{cm})$ and acoustics-derived volumetric abundance estimates obtained from the amplitude-echograms $\left(A_{\text {Tot }}\right.$, fish $\left.1000 \cdot \mathrm{m}^{-3}\right)$. Regression models and their statistics are given in Table V. Note that data are $\log _{10}(x+1)$ transformed.

et al., 2009). However, we did not identify any significant difference in the acoustics-derived fish density and mean fish size over consecutive measurements by trials, suggesting that fish avoidance could not be a serious problem in this case. More specific studies with horizontal beaming agreed with the present observations and concluded that in Central European waters, including Lake Balaton, fish avoidance generally has only a minor importance, and some effect was found only in the smallest fish $(T S<-40 \mathrm{~dB})$ close $(<10 \mathrm{~m})$ to the boat (Draštik and Kubečka, 2005; Godlewska et al., 2009).

Further criterion of an accurate acoustic survey is that fish should sufficiently be dispersed enabling their detection mostly as individual targets (single echoes). In this study, the mean share of single echoes was more than $60 \%$ that is quite a useful ratio (see e.g. Mehner and 


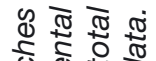

ปิ

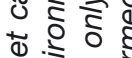

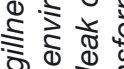

t)

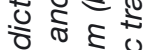

बल

दे च

$\therefore$ 의

인

d.

ำ

ᄃ

है

ब․ำ ฮิ

क ब

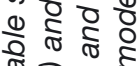

त्र

จ

ه 8 ब

공ำ

을

के क्ष

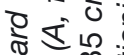

उष्

닐

हैป

政施

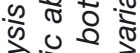

बृ के वे

ब 0 잉

ธิ ซ

के 0 \&

○ ळ

\&

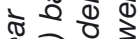

¿ 1

ब 2

(1) ?

经造

ह่ं

넝

ह

सक्य

d n 40

खे के ऐ

क है ब

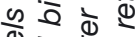

व 0

저

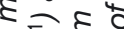

व +50

की

ज

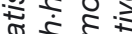

के क्ष

o wi 웅

สำ

온호

बे बे

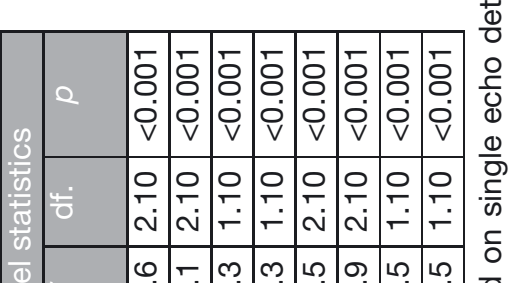

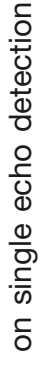

岗

సิ

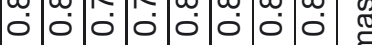

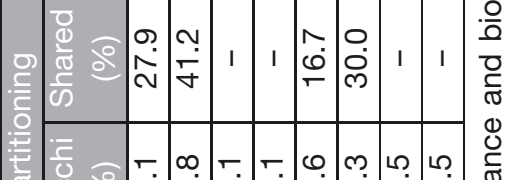

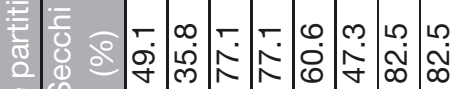

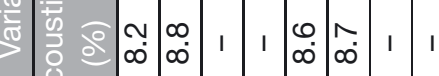

$\infty$

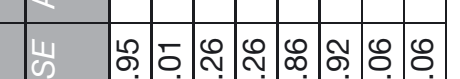

๑

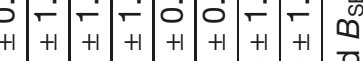

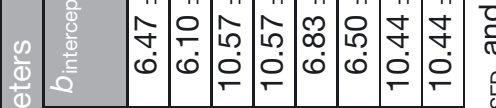

จ

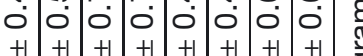

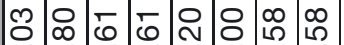

ஸ்

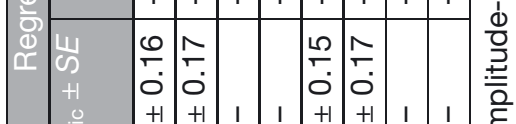
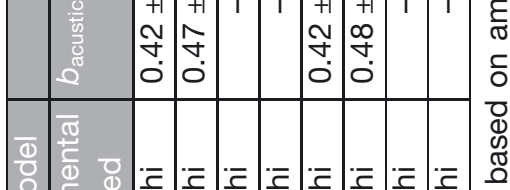

일

อ
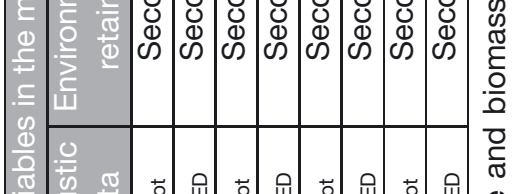

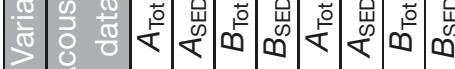

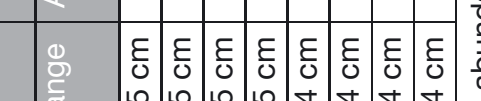

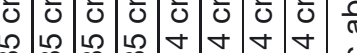

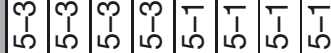

$\frac{0}{0}$

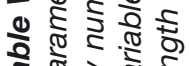

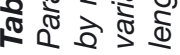

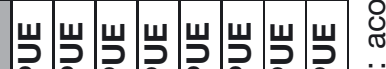


Schulz, 2002) concerning also the robust number of single targets detected and that in horizontal beaming the probability of overlapping targets is higher compared to vertical beaming. For all that the share of single echoes (35.9-89.6\%) varied considerately among trials, multiple linear regression models based on the data from either amplitude-echograms $\left(A_{\text {Tot }}\right)$ and SED-echograms $\left(A_{S E D}\right)$ gave similarly good predictions on the gillnet NPUE. Moreover, the variable "aggregation level" did not have a significant contribution to the regression model assessing the relationship between the density estimates of the two gears.

In horizontal acoustics, a further problem is that the records are often relatively noisy, which makes the identification of small fish difficult and may result their underestimation (Draštík et al., 2009). According to our preliminary studies, if the amplitude of waves exceeds about $10 \mathrm{~cm}$, horizontal beaming in the uppermost water layer of Lake Balaton becomes problematic and the echograms practically are unprocessable because of the low signal-to-noise ratio (i.e. bubbles, disturbed sediment particles and reverberation from the water surface). Though all sampling trials were performed under waveless conditions, records were yet noisy (probably because we measured very close to the surface of the water, some bubbles and surface reverberation might be presented even under calm weather conditions) and post-processing filtering was needed. Moreover, in horizontal acoustics the TS of small fish recorded from a head/tail aspect is as low that generally they are filtered out during the post-processing (Draštík et al., 2009; Kubečka et al., 2009). For example, in the present case the postprocessing TS threshold was increased to $-55 \mathrm{~dB}$ due to the noisy environment. This TS threshold corresponds to $L=2.5 \mathrm{~cm}$ in side aspect but to $L=25.6 \mathrm{~cm}$ in head/tail aspect. This means that how much shorter the fish is to $26 \mathrm{~cm} L$ the higher the probability that it will be filtered out together with the noise. Consequently, it is likely that the underestimation of small fish by acoustics may partly be a post-processing error. Further, we observed that in most cases bleak were entangled in highest density in the uppermost $20 \mathrm{~cm}$ of gillnets, this water layer is however un-investigable with acoustics.

Length and biomass of fish cannot directly be derived from acoustic data; these metrics are calculated via sophisticated procedures including parameter estimations (i.e. acoustic TS and $A$ ) and subsequent conversions (i.e. converting TS to $L, L$ to $M$ and then, $A$ and $M$ to $B$ ), which relationships however vary by fish species and may change with sampling circumstances (Didrikas and Hansson, 2004; Boswell et al., 2008; Godlewska et al., 2012). Accordingly, the accuracy of acoustics-derived size distribution and biomass data can be variable, and generally, it is unknown. Further, as typically we do not know the orientation of fish relative to the sound-beam axis, fish size assessment is even more problematic in horizontal acoustics. Since we had robust numbers of single echoes detected and there was not any indication on that fish were not randomly oriented, we used the de-convolution procedure to convert TS values to $L$ values (Kubečka et al., 1994; Godlewska et al., 2012). However, if a deviation from the randomness of the orientation of the fish occurs, estimated $L$ distribution and perforce, the assessed biomass will be biased as well. Additionally, TS distribution can be biased if echoes from two or more fish are overlapping and misidentified as a single fish echo. In sight of these, it is not surprising that the weak correlation observed here between acoustics and gillnetting based abundance indices could not be retained in biomass metrics. Conversion of horizontally detected $T S$ to $L$ data may be improved by using a catch basket obtained from a representative catch (Kubečka et al., 2009), which criterion is however can not be met by the strongly size selective gillnetting.

Insomuch as gear related problems generally have species-specific aspects, thus it is evident that disentangling and adjusting processes that influence comparability of results between gears should be more complicated for species rich assemblages (i.e. benthic and littoral assemblages) than for stocks comprised by one or few species (i.e. pelagic or surface oriented fish assemblages). However, the comparison of data obtained from gillnetting and hydroacoustics seems to be problematic even for homogeneous stocks. Though the same areas were sampled in the same time with the two gears, and there were only two dominant fish species with completely separated size ranges, no consistency between the estimates of gillnetting and acoustics was found. Similar, experiences were reported for example for 
pelagic herring and sprat in the Baltic Sea (Hansson and Rudstam, 1995); for smelt Osmerus eperlanus (L.) in Lake Vesijärvi (Peltonen et al., 1999) and vendace Coregonus albula (L.) in Lake Stechlin (Mehner and Schulz, 2002).

To conclude, we found that neither of the gears studied provided a representative picture about the fish assemblage inhabiting the uppermost water layer of Lake Balaton, thus gillnetting and acoustics should be used parallel to complement each other. However, the feasibility of establishing a powerful model describing the relationship between fish density estimates of gillnetting and acoustics is low in shallow and turbid habitats, and it might be successful only if the crucial sampling and environmental parameters affecting catching efficiency of gillnets and post-processing of acoustic data are also considered. This study cautions again that gillnet CPUE should be used carefully to analyse trends of fish abundance, and it is strongly advisable to avoid gillnetting-based abundance metrics when high accuracy is of utmost importance, for example, when critical conservation or management decisions will be based upon the conclusions. Nevertheless, gillnet samples retain their indispensable advantage over acoustics in providing information on species composition and other assemblage metrics such as growth rate, condition and diet of fish.

\section{ACKNOWLEDGEMENTS}

We are grateful to Jaroslava Frouzová, Vladislav Draštík and Jan Kubečka for their support and advice on hydroacoustic analysis. We also thank Géza Dobos for his indispensable assistance in fieldwork, and Eric Hanlon for correcting the English text. The project was funded through grants from the Hungarian Ministry of Agriculture and Rural Development, and by the National Research and Development Project (NKFP-3B/0014/2002).

\section{REFERENCES}

Appelberg M., Berger H.M., Hesthagen T., Kleiven E., Kurkilahti M., Raitaniemi J. and Rask M., 1995. Development and intercalibration of methods of Nordic freshwater fish monitoring. Water Air Soil Pollut., 85, 883-888.

Balk H., 2001. Development of hydroacoustic methods for fish detection in shallow water, Ph.D. thesis, Faculty of Mathematics and Natural Science, University of Oslo, Norway.

Balk H. and Lindem T., 2007. Sonar4 and Sonar5-Pro Post Processing Systems, Operator Manual, Version 5.9.7. Balk and Lindem Data Acquisition, Oslo, Norway.

Bíró P., 1997. Temporal variation in Lake Balaton and its fish populations. Ecol. Freshwater Fish, 6, 196-216.

Boswell K.M., Wilson M.P. and Wilson C.A., 2007. Hydroacoustics as a tool for assessing fish biomass and size distribution associated with discrete shallow water estuarine habitats in Louisiana. Estuar. Coast., 30, 607-617.

Boswell K.M., Kaller M.D., Cowan Jr.J.H. and Wilson C.A., 2008. Evaluation of target strength-fish length equation choices for estimating estuarine fish biomass. Hydrobiologia, 610, 113-123.

Boswell K.M., Wilson M.P., MacRae P.S.D., Wilson C.A. and Cowan Jr.J.H., 2010. Seasonal estimates of fish biomass and length distributions using acoustics and traditional nets to identify estuarine habitat preferences in Barataria Bay, Louisiana. Marine \& Coastal Fisheries, 2, 83-97.

CEN (European Committee for Standardization), 2005. Water quality - Sampling of fish with multi-mesh gillnets (14757:2005), CEN, Brussels.

Deceliere-Vergés C., Argillier C., Lanoiselée C., De Bortoli J. and Guillard J., 2009. Stability and precision of the metrics obtained using CEN multi-mesh gillnets in natural and artificial lakes in France. Fish. Res., 99, 17-25.

Dennerline D.E., Jennings C.A. and Degan D.J., 2012. Relationships between hydroacoustic derived density and gill net catch: Implication for fish assessments. Fish. Res., 123-124, 78-89.

Didrikas T. and Hansson S., 2004. In situ target strength of the Baltic Sea herring and sprat. ICES J. Mar. Sci., 61, 378-382. 
Draštík V. and Kubečka J., 2005. Fish avoidance of acoustic survey boat in shallow waters. Fish. Res., 72, 219-228.

Draštík V., Kubečka J., Čech M., Frouzová J., Říha M., Jůza T., Tušer M., Jarolím O., Prchalová M., Peterka J., Vašek M., Kratochvíl M., Matěna J. and Mrkvička T., 2009. Hydroacoustic estimates of fish stocks in temperate reservoirs: day or night surveys? Aquat. Living Resour., 22, 69-77.

Elliott J.M. and Fletcher J.M., 2001. A comparison of three methods for assessing the abundance of Arctic char, Salvelinus alpinus, in Windermere (northwest England). Fish. Res., 53, 39-46.

Emmrich M., Helland L.P., Busch S., Schiller S. and Mehner T., 2010. Hydroacoustic estimates of fish densities in comparison with stratified pelagic trawl sampling in two deep, coregonid-dominated lakes. Fish. Res., 105, 178-186.

Erős T., Heino J., Schmera D. and Rask M., 2009a. Characterising functional trait diversity and traitenvironment relationships in fish assemblages of boreal lakes. Freshw. Biol., 54, 1788-1803.

Erős T., Specziár A. and Bíró P., 2009b. Assessing fish assemblages in reed habitats of a large shallow lake - A comparison between gillnetting and electric fishing. Fish. Res., 96, 70-76.

Frouzová J., Kubečka J., Balk H. and Frouz J., 2005. Target strength of some European fish species and its dependence on fish body parameters. Fish. Res., 75, 86-96.

Gjelland K.Ø., Bøhn T., Knudsen F.R. and Amundsen P.A., 2004. Influence of light on the swimming speed of coregonids in subarctic lakes. Ann. Zool. Fennici, 41, 137-146.

Godlewska M., Długoszewski B. and Doroszczyk L., 2009. Day/night effects of passing boat on fish distribution in the shallow Malta Reservoir. Hydroacoustics, 12, 61-68.

Godlewska M., Colon M., Jóźwik A. and Guillard J., 2011. How pulse lengths impact fish stock estimations during hydroacoustic measurements at $70 \mathrm{kHz}$. Aquat. Living Resour., 24, 71-78.

Godlewska M., Frouzova J., Kubečka J., Wiśniewolski W. and Szlakowski J., 2012. Comparison of hydroacoustic estimates with fish census in shallow Malta Reservoir - which $T S / L$ regression to use in horizontal beam applications? Fish. Res., 123-124, 90-97.

Guillard J. and Vergès C., 2007. The repeatability of fish biomass and size distribution estimates obtained by hydroacoustic surveys using various sampling strategies and statistical analyses. Internat. Rev. Hydrobiol., 92, 605-617.

Hamley J.M., 1975. Review of gillnet selectivity. J. Fish. Res. Board Can., 32, 1943-1969.

Hansson S. and Rudstam L.G., 1995. Gillnet catches as an estimate of fish abundance: a comparison between vertical gillnet catches and hydroacoustic abundances of Baltic Sea herring (Clupea harengus) and sprat (Sprattus sprattus). Can. J. Fish. Aquat. Sci., 52, 75-83.

Herodek S., Laczkó L. and Virág Á., 1988. Lake Balaton: Research and Management, Nexus, Budapest.

Holmgren K. and Appelberg M., 2000. Size structure of benthic freshwater fish communities in relation to environmental gradients. J. Fish Biol., 57, 1312-1330.

Istvánovics V., Clement A., Somlyódy L., Specziár A., Tóth L.G. and Padisák J., 2007. Updating water quality targets for shallow Lake Balaton (Hungary), recovering from eutrophication. Hydrobiologia, 581, 305-318.

Jackson D.A. and Harvey H.H., 1997. Qualitative and quantitative sampling of lake fish communities. Can. J. Fish. Aquat. Sci., 54, 2807-2813.

Janáč M. and Jurajda P., 2005. Inter-calibration of three electric fishing techniques to estimate 0+ juvenile fish densities on sandy river beaches. Fish. Manage. Ecol., 12, 161-167.

Knudsen F.R. and Sægrov H., 2002. Benefits from horizontal beaming during acoustic survey: application to three Norwegian lakes. Fish. Res., 56, 205-211.

Kubečka J. and Wittingerova M., 1998. Horizontal beaming as a crucial component of acoustic fish stock assessment in freshwater reservoirs. Fish. Res., 35, 99-106.

Kubečka J., Duncan A., Duncan W.M., Sinclair D. and Butterworth A.J., 1994. Brown trout populations of three Scottish lochs estimated by horizontal sonar and multi-mesh gillnets. Fish. Res., 20, 29-48.

Kubečka J., Frouzová J., Balk H., Čech M., Draštík V. and Prchalová M., 2009. Regressions for conversion between target strength and fish length in horizontal acoustic surveys. In: Papadakis J.S. and Bjorno L. (eds.), Underwater acoustic measurements, Technologies \& Results, Foundation for Research \& Technology, Heraklion, Greece, 1039-1044.

Lauridsen T.L., Landkildehus F., Jeppesen E., Jørgensen T.B. and Søndergaard M., 2008. A comparison of methods for calculating Catch Per Unit Effort (CPUE) of gill net catches in lakes. Fish. Res., 93, 204-211. 
Linløkken A. and Haugen T.O., 2006. Density and temperature dependence of gill net catch per unit effort for perch, Perca fluviatilis, and roach, Rutilus rutilus. Fish. Manage. Ecol., 13, 261-269.

Mehner T. and Schulz M., 2002. Monthly variability of hydroacoustic fish stock estimates in a deep lake and its correlation to gillnet catches. J. Fish Biol., 61, 1109-1121.

Mehner T., Diekmann M., Brämic U. and Lemcke R., 2005. Comparison of fish communities in German lakes as related to lake morphology, trophic state, shore structure and human use intensity. Freshw. Biol., 50, 70-85.

Millar R.B., 2000. Untangling the confusion surrounding the estimation of gill net selectivity. Can. J. Fish. Aquat. Sci., 57, 507-511.

Mous P.J., van Densen W.L.T. and Machiels M.A.M., 2004. Vertical distribution patterns of zooplanktivorous fish in shallow, eutrophic lake, mediated by water transparency. Ecol. Freshwat. Fish., 13, 61-69.

Murphy B. and Willis D. (eds.), 1996. Fisheries Techniques, 2nd edition, American Fisheries Society, Bethesda, Maryland.

Olin M. and Malinen T., 2003. Comparison of gillnet and trawl in diurnal fish community sampling. Hydrobiologia, 506-509, 443-449.

Olin M., Kurkilahti M., Peitola P. and Ruuhijärvi J., 2004. The effects of fish accumulation on the catchability of multimesh gillnet. Fish. Res., 68, 135-147.

Peltonen H., Ruuhijärvi J., Malinen T. and Horppila J., 1999. Estimation of roach (Rutilus rutilus (L.)) and smelt (Osmerus eperlanus (L.)) stocks with virtual population analysis, hydroacoustics and gillnet CPUE. Fish. Res., 44, 25-36.

Pierce R.B., Tomcko C.M., Pereira D.L and Staples D.F., 2010. Differing catchability among lakes: influences of lake basin morphology and other factors on gill-net catchability of northern pike. Trans. Am. Fish. Soc., 139, 1109-1120.

Prchalová M., Kubečka J., Říha M., Mrkvička T., Vašek M., Jůza T., Kratochvíl M., Peterka J., Draštík V. and Kř́žck J., 2009. Size selectivity of standardized multimesh gillnets in sampling coarse European species. Fish. Res., 96, 51-57.

Prchalová M., Mrkvičká T., Kubečka J., Peterka J., Čech M., Muška M., Kratochvíl M. and Vašek M., 2010. Fish activity as determined by gillnet catch: A comparison of two reservoir of different turbidity. Fish. Res., 102, 291-296.

Prchalová M., Mrkvičká T., Peterka J., Čech M., Berec L. and Kubečka J., 2011. A model of gillnet catch in relation to the catchable biomass, saturation, soak time and sampling period. Fish. Res., 107, 201-209.

Rakowitz G., Kubečka J., Fesl C. and Keckeis H., 2009. Intercalibration of hydroacoustic and markrecapture methods for assessing the spawning population size of a threatened fish species. J. Fish Biol., 75, 1356-1370.

Simmonds J. and MacLennan D., 2005. Fisheries Acoustics: Theory and Practice, 2nd edition, Blackwell Science, Oxford.

Specziár A., 2010. Fish fauna of Lake Balaton: stock composition, living conditions of fish and directives of the modern utilization of the fish stock. Acta Biol. Debr. Suppl. Oecol. Hung., 23 (Hydrobiol. Monogr. 2), 7-185 (in Hungarian with an English summary).

Specziár A., Erős T., György Á.l., Tátrai I. and Bíró P., 2009. A comparison between the Nordic gillnet and whole water column gillnet for characterizing fish assemblages in the shallow Lake Balaton. Ann. Limnol., 45, 171-180.

Tátrai I., Specziár A., György Á.I. and Bíró P., 2008. Comparison of fish size distribution and fish abundance estimates obtained with hydroacoustics and gill netting in the open water of a large shallow lake. Ann. Limnol. Int. J. Lim., 44, 231-240.

Tušer M., Kubečka J., Frouzová J. and Jarolíma O., 2009. Fish orientation along the longitudinal profile of the Římov reservoir during daytime: Consequences for horizontal acoustic surveys. Fish. Res., 96, 23-29.

Vašek M., Kubečka J., Čech M., Draštík V., Matěna J., Mrkvičká T., Peterka J. and Prchalová M., 2009. Diel variation in gillnet catches and vertical distribution of pelagic fishes in a stratified European reservoir. Fish. Res., 96, 64-69.

Winfield I.J., Fletcher J.M., James J.B. and Bean C.W., 2009. Assessment of fish populations in still waters using hydroacoustics and survey gill netting: Experiences with Arctic char (Salvelinus alpinus) in the UK. Fish. Res., 96, 30-38. 